\title{
СТРАТЕГИЯ РАБОТЫ РЕЛИГИОЗНЫХ ОБЪЕДИНЕНИЙ С ИММИГРАНТАМИ: ОТ СОЦИАЛЬНОЙ АДАПТАЦИИ К МИССИИ
}

\begin{abstract}
Аннотация. В статье проанализирована роль религиозных объединений в работе с мигрантами из разных стран на примере деятельности ряда христианских ичерквей в России и странах Европейского союза. Активность иерквей в среде мигрантов имеет особое значение в условиях, когда волны внутренней миграции и иммиграџионного кризиса затрагивают в той или иной степени всё евразийское пространство. Стратегия христианских миссий выстраивается на основе сочиального служения, а не прямой миссии по привлечению мигрантов в свои обшины. Больиинство мигрантов (к примеру, в России с Северного Кавказа) или иммигрантов (из Центральной Азии или Ближнего Востока) принадлежат к мусульманской культуре и являются выходиами из общества с традиционным клановым укладом. В связи с этим миссия среди мигрантов исходит из необходимости, в первую очередь, сочиально-правовой помощи и сочиальной адаптации для тех, кто в этом нуждается. Культурная и религиозная миссии являются следующим этапом интеграџии мигрантов в общество.
\end{abstract}

Ключевые слова: миграция, межрелигиозный диалог, христианство, протестантизм, православие, католищизм, государственно-иерковные отношения.

Активность религиозных объединений в среде мигрантов имеет особое значение в условиях, когда волны внутренней миграции и иммиграционного кризиса затрагивают в той или иной степени всё евразийское пространство. Большинство мигрантов (к примеру, в России с Северного Кавказа) или иммигрантов (из Центральной Азии в России или Ближнего Востока в Европе) принадлежат к мусульманской культуре и являются выходцами из общества с традиционным клановым укладом. Миссией среди мигрантов из разных стран, в основном, занимаются различные христианские церкви в России и странах Европейского союза (православные, католики, протестанты) ${ }^{1}$. Мигранты сталкиваются с безработицей, нищетой, непониманием местных законов, в целом испытывают отчуждение от окружающего общества (как правило, мегаполиса). В связи с этим миссия среди мигрантов исходит из необходимости, в первую очередь, социально-правовой помощи и социальной адаптации для тех, кто в этом нуждается. Культурная и религиозная миссии являются следующим этапом интеграции мигрантов в окружающее общество. Стратегия христианских миссий выстраивается на основе социального служения, и у каждой конфессии и конкретной церкви существуют свои особенности перехода от социального аспекта служения к миссии по привлечению мигран-

(С Лункин Роман Николаевич - кандидат философских наук, доктор политических наук, ведущий научный сотрудник, руководитель Центра по изучению проблем религии и общества ИЕ РАН, заместитель главного редактора журнала «Современная Европа». Aдрес: 125009, Россия, Москва, Моховая ул., дом 11, стр. 3. $\boldsymbol{E}$-mail: romanlunkin@ gmail.com.

DOI: http://dx.doi.org/10.15211/vestnikieran120197783

1 Лункин Р.Н. Миссия милосердия: социальное служение церквей. Современная Европа. №4(70), 2016. С. 154158. 
тов в свои общины.

Один из ярких примеров подобной миссии - деятельность протестантской церкви «Слово жизни» в Москве (основана в начале 1990-х гг. миссионерами из Швеции и Норвегии). Руководителем служения среди мигрантов является пастор Андрей Мриль, он родился в Узбекистане и потом переехал в Россию, но по-прежнему хорошо понимает, как надо общаться с выходцами из республик Центральной Азии ${ }^{1}$. Миссия в Москве началась в 2006 г., к этому времени уже была группа верующих из киргизов и свои национальные служители. По признанию пастора, в мегаполисе этнические границы, которые очевидны на родине, стираются, и узбеки, таджики, киргизы становятся единым целым (казахов среди иммигрантов меньше, и они считаются более образованными). Кроме того, они сталкиваются с одними и теми же проблемами, а местное население их не различает.

Религиозная миссия церкви сталкивается с целым рядом трудностей. Прежде всего, это связано с определённым пониманием Иисуса Христа как пророка, почти такого же, как пророк Мухаммед. С именем Христа связано только то, что он «человек и пророк». Помимо этого, когда выходцам из Центральной Азии говорят о церкви, то они представляют себе исключительно православный храм, здание, а не что-либо иное, более абстрактное богословское понятие (православие при этом считается только «русской верой»). $90 \%$ иммигрантов в той или иной степени воспитаны в религиозной мусульманской среде, они твёрдо убеждены, что православная церковь - «не наша», а поэтому и прямое приглашение в церковь вызывает у них противление. Это священное пространство, но не для них. По словам пастора, «у них как будто вставлен какой-то свой религиозный антивирус. Если кто-то ходит в храм или пришёл ко Христу, то он становится предателем».

В связи с этим работа с выходцами из Азии начинается на социальном уровне, с помощи и содействия оформлению документов, жилья, работы, юридического сопровождения в легализации (как правило, первая консультация бесплатно), помощи в бытовых нуждах. Церковь находит нерелигиозную площадку для того, чтобы помогать и общаться с иммигрантами. Если таджика или киргиза приглашают прямо в церковь, то он, как правило, разворачивается и уходит из-за надписи «Христианская церковь» (это надпись на здании церкви «Слово жизни» в Москве у м. Алексеевская), даже если человека приглашали на юридическую консультацию. Поэтому в данной сфере чрезвычайно важна социальная основа. В рамках волонтёрского проекта распространяются объявления с предложением помочь с регистрацией и работой, некоторым церковь помогает снимать квартиру, других устраивает в строительные бригады. С 2011 г. волонтёры кормят нуждающихся на Казанском вокзале, на который прибывает много поездов с Юга, многие люди там теряют документы, их обманывают, они остаются без средств. Бомжей вначале отправляют в Центр восстановления (ребцентр), а затем уже устраивают на работу. Среди реабилитантов есть и представители интеллигенции и бывшие уголовники. По желанию они могут посещать библейские курсы и богослужения, после чего некоторые остаются в церкви, но большинство уезжает на родину.

В рамках существующей христианской общины выходцев из Центральной Азии (Азиатское служение церкви) богослужение проводится на русском языке, поскольку среди верующих представители нескольких национальностей. Однако «прославление», то есть пение христианских песен, проходит уже на разных языках, также и проповеди иногда проходят на родных языках в зависимости от того, какая группа собирается. Музыкальная церковная группа состоит из узбеков и таджиков. Всего в московской азиатской общине «Слово жизни» со-

\footnotetext{
${ }^{1}$ Информация о миссии церкви среди мигрантов основана на полевом материале автора - социологическое интервью с пастором церкви «Слово жизни» Андреем Мрилем от 09.02.2019.
}

Научно-аналитический вестник ИЕ РАН, 2019, №1 
бирается до 80 чел. Как отмечает пастор Андрей Мриль, «сколько соберётся людей, зависит от погоды, проверок и наличия полиции рядом». Раз в год в церкви празднуют Навруз, который объединяет всех выходцев из Центральной Азии.

Внутрицерковная работа включает в себя два формата - «храмовый», то есть собрания непосредственно в церкви, и домашние группы, которые могут собираться на квартирах. Собрания домашних групп по своему́ стилю больше приближены к азиатской культуре - все сидят на матрасах на полу, периодически делают плов, читают Священное Писание на узбекском и таджикском языках. Как отмечает пастор А. Мриль, «у нас нет задачи ломать культуру, мы, наоборот, хотим сохранить азиатские обычаи, но мы разделяем культуру и религию, есть моменты, где мы ставим черту». Пить из пиалы чай и есть плов руками, что делают далеко не все, это культурные элементы. Совершение молитвы (намаза) после еды - это религиозная часть. На домашних группах протестантские служители молятся вместе с бывшими или считающими себя мусульманами, поднимая руки вверх и совершая омовение лица, как все мусульмане. При этом в качестве молитвы читается «Отче наш». Многие из тех, кто приходит на домашние группы, знакомятся через социальные сети, их приглашают на «азиатские встречи», а не на богослужения.

Часть протестантских общин Европы и США, которые занимаются миссией в мусульманской среде, использует слово «Аллах» для обозначения Бога. Другая часть считает, что у мусульман Бог не является аналогом библейского Бога - Элохима, а мусульмане поклоняются «духу пустыни» (такого же мнения, к примеру, придерживался и священник РПЦ Даниил Сысоев, обращавший мусульман в православие, убит в 2009 г. по религиозным мотивам). В церкви «Слово жизни» придерживаются мнения, что семантика у понятия «Аллах» может быть разная, надо просто корректно это слово использовать.

Как и в странах Европейского союза, иммигранты и в России сталкиваются с религиозно-культурным диссонансом вокруг себя. Окружающую культуру секулярного общества они ассоциируют с христианством, даже если эта культура включает в себя свободное отношение, по их мнению, к стилю одежды, разврату, алкоголю и т.д. Многие иммигранты, по признанию служителей церквей, боялись принять Христа, так как боялись стать такими же, как все люди вокруг. В связи с этим протестантские миссионеры, в первую очередь, говорят о том, что они «проповедуют не религию, а Христа, не культуру, а спасение».

В отличие от христианской миссии в самих мусульманских регионах или на Ближнем Востоке в европейском мегаполисе проблемы с мусульманским родственным окружением почти не возникает. Соплеменники могут назвать новообращенного христианина «кяфиром», предателем веры своих отцов, но в большом городе всегда легко раствориться или уехать, что на родине сделать сложнее. Многие прошедшие библейские курсы в церквях за пределами своего дома становятся христианами, но боятся об этом говорить среди родственников. Однако в настоящее время и среди выходцев из Центральной Азии постепенно ломается стереотип о том, что если ты узбек, киргиз и т.д., то ты должен быть обязательно мусульманином.

В протестантской среде специальная миссия среди мигрантов в больших городах чрезвычайно распространена. В московской церкви «Слово жизни», помимо «азиатского служения» для выходцев из Центральной Азии, есть группа выходцев из Вьетнама и Малайзии. Самостоятельная церковь есть у христиан, приехавших из Узбекистана (собирается в Реутове). В пятидесятнической Церкви «Благая Весть» (пастора из США Рика Реннера) в Москве есть киргизская группа. Некоторые миссионеры ведут занятия по русском и английскому языку в районе крупных рынков. В одном из районов Москвы узбекское служение действует в рамках корейской пресвитерианской церкви. Своё мигрантское полуподпольное служение сущест- 
вует в Санкт-Петербурге («пятидесятническая церковь «Свет Азии»).

Внутри протестантских конфессий есть свои различия в подходе к служению среди иммигрантов из разных стран: пятидесятники сочетают социальную работу с евангелизацией и обращением в веру, баптисты более целенаправленно привлекают в церковь, либеральные лютеранские церкви отодвигают обращение в веру на второй или третий план. Отличие ситуации в России от стран Европейского союза (в значительной степени Западной Европы) состоит в том, что в России национальные общины являются частью более крупных русскоязычных церквей, тогда как в Европе за последние 10-15 лет появились самостоятельные национальные церкви выходцев из Африки, Ближнего Востока, Турции, Латинской Америки, где уже коренные европейцы представляют меньшую часть новообращённых ${ }^{1}$.

Ярким примером миссии служит проект гуманитарных коридоров, который был предложен в 2015 г. и реализуется с 2016 г., пока только на территории Италии. Инициаторами проекта стали католическая община св. Эгидия, Вальденсийская церковь и Евангельская федерация церквей. Идея проекта заключается в том, чтобы выдавать гуманитарные визы и проверять документы мигрантов перед отъездом беженцев в Европу (предполагается переправлять около 1 тыс. в год). Для этого целый ряд итальянских консульств открыли свои бюро в Ливии, Эфиопии и Марокко. Одна из целей проекта - найти альтернативное решение миграционных проблем для того, чтобы обеспечить безопасность и управлять миграцией. Общее мнение, в том числе и представителей церквей, состоит в том, что Европа стареет и нуждается в мигрантах. А мигранты, которые прибывают и устраиваются легально, платят налоги и улучшают ситуацию. Гуманитарное соображение состоит в том, чтобы Средиземное море не было кладбищем под открытым небом. Кризис 2014-2017 гг. носит политический и психологический характер - страх перед мигрантами велик, но численность мигрантов не столь катастрофична для Европы. Это всего около 1 млн беженцев на весь Евросоюз, хотя в Ливане на 6 млн населения 1,5 млн беженцев (интервью автора с Алессандро Салаконе, представителем Общины Св. Эгидия в России в мае 2015 г.). Реализации этого проекта способствовал член Общины св. Эгидия - заместитель министра иностранных дел Италии Марио Джиро (ранее общественными связями в Общине св. Эгидия). В связи с этим проектом стали более актуальными и многие идеи, которые популярны в этой общине - Евроафрики и Африки как европейской границы.

Логическим продолжением переселения легальных иммигрантов в Европу является работа с ними. Община св. Эгидия организовала проект «Люди, ищущие мира», членами которого являются мусульмане. В 1982 г. община св. Эгидия организовала курсы итальянского языка, чтобы люди не закрывались и интегрировались в окружающее общество. За 30 лет через эти курсы прошло несколько сот тысяч людей. Община специально не создавала мононациональные группы, а в различных праздниках участвовали все члены проекта - вместе праздновали Рождество и Рамадан, привлекали к волонтёрской работе всех, независимо от вероисповедания и нации (желающие, мусульмане и христиане, ходили по тюрьмам и больницам и т.д. $)^{2}$.

Именно в рамках этого проекта гуманитарных коридоров папа Франциск, посетивший лагерь беженцев на греческом острове Лесбос, взял с собой в Ватикан 12 сирийских мигрантов, тех, у которых были оформлены предварительно гуманитарные визы. Идеология Общи-

\footnotetext{
${ }^{1}$ Европа XXI века. Новые вызовы и риски. Монография. Под общей ред. Ал.А. Громыко, В.П. Фёдорова. М., СПб.: Нестор-История, 2017. 584 с. Серия: Старый Свет - новые времена. Федеральное гос. бюджетное учреждение науки Ин-т Европы Российской акад. наук. С. 100-122.

${ }^{2}$ Современная Италия: старые проблемы, новые вызовы. Отв. ред. Е.А. Маслова. М.: Ин-т Европы РАН, 2018. C. $79-91$
}

Научно-аналитический вестник ИЕ РАН, 2019, №1 
ны св. Эгидия отражает взгляды папы Франциска на ситуацию с беженцами и роль Европы в современном мире. Это и провозглашение солидарности и милосердия к нищим и переселенцам, отрицание как европоцентризма, так и колониализма. Прагматизм Церкви заключается в том, что в Африке проживает уже около трети всех христиан мира. Именно поэтому будущее - в дополняющих друг друга культурах, а не в мультикультурализме и не в дискриминации «чужих» культур. С этих позиций представители общины св. Эгидия критикуют «правых» политиков в Польше и Венгрии и целый ряд епископов в этих и других странах, которые призывают оградить Европу от мигрантов. Отдельно существует иезуитский центр беженцев в Европе. Общий принцип такого рода центров - предоставлять помощь беженцам, давать им инструкции для жизни и требовать от них уважения к европейским нормам жизни 1 .

В рамках Русской православной церкви долгое время не было целенаправленной работы с иммигрантами, хотя отдельные инициативы существовали ${ }^{2}$. В 2006-2009 гг. активным миссионерством в мусульманской среде занимался Миссионерский центр свящ. Даниила Сысоева, который фактически за свою миссию был убит в 2009 г. В 2014 г. был принят официальный документ «Принципы и направления работы с мигрантами в РПЦ», который провозгласил принципы милосердия (странноприимства) и межрелигиозного диалога: «Церковная работа с мигрантами, многие из которых исповедуют традиционные нехристианские религии, неотделима от межрелигиозного диалога. Церковь, уважая убеждения людей, исповедующих другие традиционные религии, одновре́менно считает возможным их культурологическое знакомство с религиозными традициями страны пребывания, а также способствует их вовлечению в жизнь тех общин своих единоверцев, которые известны конструктивной деятельностью в принимающем обществе» ${ }^{3}$.

С 2018 г. был запущен «азиатский» проект РПЦ под патронажем Комиссии по миссионерству и катехизации Епархиального управления Москвы по переводу церковной литературы на языки народов Средней Азии. Тогда ещё диакон Дионисий Гришков, руководитель центра социальной помощи мигрантам при храме Евфросинии Московской в Котловке, отмечал, что проект зародился достаточно давно среди рядовых московских миссионеров, в том числе из мигрантской среды. По словам отца Дионисия, «необходимость в переводе церковной литературы появилась, так как в Москве уже есть крещёные жители Средней Азии. Хочу устроить их первую встречу, организовать для них богослужение с элементами национальных языков. Для этого недавно перевели на узбекский и киргизский языки часослов, на таджикский молитвослов. Нам приходится обращаться к помощи профессионалов переводчиков. Зачастую они - крещёные в протестантских общинах носители языка... Все народы Средней Азии имеют свою христианскую историю. Но даже если бы не было, это долг Церкви - заботится об исполнении заповеди научить все народы» ${ }^{4}$. В 2019 г. при московском храме Евфросинии Московской была открыта школа русского языка для детей мигрантов, где педагоги, логопеды и волонтёры будут готовить их к начальной школе. В школе три возрастные группы, в которых обучаются 16 человек. В планах школы - создать группу по подготовке к выпускным экзаменам детей из старшей школы и благотворительный Детский сад. Также планируется

\footnotetext{
${ }^{1}$ Mapping migration, mapping churches' responses in Europe: Belonging, Community, and Integration: the Witness and Service of Churches in Europe. Churches' Commission for Migrants in Europe. 2016. URL: http://www.ccme.be/filead min/filer/ccme/70_DOWNLOADS/20_Publications/2016-01-08-Mapping_Migration_2015_Online_lo-res__2_.pdf.

${ }_{2}^{2}$ Митрофанова А.В. Социальная работа православных некоммерческих организаций: направления, цели, типология. Гуманитарные науки. Вестник Финансового университета. 2013. №1. С. 32-43.

3 Принципы и направления работы с мигрантами в Русской Православной Церкви. 20 ноября 2014 г. Патриархия.Ru. Документ согласован на заседании Высшего Церковного Совета 13 ноября 2014 г.

${ }^{4}$ Приймак А. Литургия для трудовых мигрантов. Не найдя себя в исламе, уроженцы Средней Азии заполняют духовную пустоту православием. Независимая газета (НГ-Религии). 18.07.2018.
}

Научно-аналитический вестник ИЕ РАН, 2019, №1 
открыть несколько филиалов в разных районах Москвы ${ }^{1}$.

Стратегия работы религиозных объединений (христианских церквей) с мигрантами включает в себя несколько этапов: социальная поддержка, интеграция в общество, привлечение к околоцерковной активности, становление мигранта как члена общины или человека, который, по крайней мере, симпатизирует этой общине и не боится её. Протестанты и католики оказались в наибольшей степени вовлечены в эту миссию, именно у этих конфессий есть свои наиболее развитые и доказавшие свою эффективность на практике проекты и миссионерские церкви. В России мигрантами занимаются, в первую очередь, протестантские церкви разных направлений (евангельский протестантизм - баптисты, евангелисты, пятидесятники) ${ }^{2}$. Представители РПЦ находятся только в начале пути своего служения в этой сфере, но в значительной степени они повторяют опыт католиков и протестантов. Если протестантские конфессии делают упор именно на социальной адаптации и интеграции, а миссионерская деятельность идёт следом или даже параллельно, то православные и католики делают упор на культурной миссии - сочетании образования, изучения местной культуры и правовой интеграции в общество и трудовую деятельность. Протестанты прямо говорят о своём намерении евангелизировать мигрантов (исключение - либеральные церкви, к примеру, лютеранские церкви в Скандинавии, которые работают с мусульманами и помогают им, но прямо не ставят целью их обращение в веру). Для православных и католиков также на первом плане в рамках их работы с мигрантами - не воцерковление, а скорее включение приезжих в свой культурный контекст, тогда как для многих евангелистов такой контекст не является значимым в рамках их мировоззрения. Вместе с тем и тот и другой подходы к социально-миссионерской деятельности ведут, во-первых, к разносторонней интеграции иммигрантов в общественную среду, а во-вторых, в создание благоприятной мигрантской среды, где отсутствует почва для распространения экстремистских псевдорелигиозных идей.

\section{Список литературы}

Европа XXI века. Новые вызовы и риски. Монография. Под общей ред. Ал.А. Громыко, В.П. Фёдорова. М., СПб.: Нестор-История, 2017. 584 с. Серия: Старый Свет - новые времена. Федеральное гос. бюджетное учреждение науки Ин-т Европы Российской акад. наук. С. 100122.

Лункин Р.Н. Миссия милосердия: социальное служение церквей. Современная Европа. №4(70), 2016. С. 154-158.

Митрофанова А.В. Социальная работа православных некоммерческих организаций: направления, цели, типология. Гуманитарные науки. Вестник Финансового университета. 2013. №1. С. 32-43.

Партии и движения политической альтернативы в современной Европе. Сб. статей. Отв. ред. В.Я. Швейцер. М.: Ин-т Европы РАН, 2018. С. 36-53.

Религиозные миссии на общественной арене: российский и зарубежный опыт. Колл. моногр. Под ред. А.А. Красикова и Р.Н. Лункина. Центр по изучению проблем религии и о-ва ИЕ РАН. М.: ИЕ РАН, 2016.

Современная Италия: старые проблемы, новые вызовы. Отв. ред. Е.А. Маслова. М.: Ин-т

\footnotetext{
${ }^{1}$ РПЦ открыла в Москве бесплатную школу русского языка для детей мигрантов. Интерфакс-Религия. 19 февраля 2019 г.

2 Религиозные миссии на общественной арене: российский и зарубежный опыт. Колл. моногр. под ред. А.А. Красикова и Р.Н. Лункина. Центр по изучению проблем религии и о-ва ИЕ РАН. М.: ИЕ РАН, 2016.

Научно-аналитический вестник ИЕ РАН, 2019, №1
} 
Европы РАН, 2018. С. 79-91.

Mapping migration, mapping churches' responses in Europe: Belonging, Community, and Integration: the Witness and Service of Churches in Europe. Churches' Commission for Migrants in Europe. 2016. URL: http://www.ccme.be/fileadmin/filer/ccme/70_DOWNLOADS/20_Publications /2016-01-08-Mapping_Migration_2015_Online_lo-res__2_.pdf.

\section{References}

Evropa XXI veka. Novye vyzovy i riski. Monografiya. Pod obschei red. Al.A. Gromyko, V.P. Fyodorova. V.: SPb.: Nestor-Istoriya, 2017. 584 s. Seriya: Staryj Svet - novye vremena. Federal'noe gos. byudzhetnoe uchrezhdenie nauki In-t Evropy Rossijskoj akad. nauk. S. 100-122.

Lunkin R.N. Missiya miloserdiya: social'noe sluzhenie cerkvej. Sovremennaya Evropa. №4 (70), 2016. S. 154-158.

Mitrofanova A.V. Social'naya rabota pravoslavnyh nekommercheskih organizacij: napravleniya, celi, tipologiya. Gumanitarnye nauki. Vestnik Finansovogo universiteta. 2013. №1. S. 32-43.

Partii i dvizheniya politicheskoj al'ternativy v sovremennoj Evrope. Sb. Statej. Otv. red. V.Ya. Shvejcer. M.: In-t Evropy RAN , 2018. S. 36-53.

Religioznye missii na obshchestvennoj arene: rossijskij i zarubezhnyj opyt. Koll. monogr. Pod red. A.A. Krasikova i R.N. Lunkina. Centr po izucheniyu problem religii i o-va IE RAN. M.: IE RAN, 2016.

Sovremennaya Italiya: starye problemy, novye vyzovy. Otv. red. E.A. Maslova. M.: In-t Evropy RAN, 2018. S. 79-91.

\section{The Strategy of the Work of Religious Associations with Immigrants: from Social Adaptation to the Mission}

Authors. Roman Lunkin, Candidate of Sciences (Philosophy), Senior Fellow, the Head of the Center for Religious Studies, Institute of Europe, Russian Academy of Sciences, deputy editorin-chief of the journal «Contemporary Europe». Address: 11-3, Mokhovaya str., Moscow, Russia, 125009. E-mail: romanlunkin@gmail.com.

Abstract. In the article analyzed the role of the religious associations in their work with migrants from different countries on the example of the activities of the set of Christian churches in Russia and European Union. That kind of mission plays a special role in the conditions when the waves of inner migration and immigrant crisis touch all Eurasian space. The Strategy of the Christian missions based on the social work, not on the direct mission for converting of the migrants in the certain communities. The main part of the migrants (in Russia, for example, from Northern Caucasus) and immigrants (from Central Asia and Middle East) belong to the muslim culture and they were come from the traditional society with its own clan rules. In connection with that the mission proceeds from the social and legal help and social adaption in the first hand for those who need it. The cultural and religious missions became the next period of the integration of the migrants into society.

Key words: migration, interreligious dialogue, Christianity, Protestantism, Orthodoxy, Catholicism, Church-State relations.

DOI: http://dx.doi.org/10.15211/vestnikieran120197783 